KAPITEL 5

\title{
Ta hand om sin egen skit
}

INGR ID: Varför jag inte vill betala för städning? Därför att ... Av flera skäl. För det första har jag bara med mig från mamma och mormor att sin egen skit tar man hand om själv och att jag också vill ta hand om mitt eget hem. Att det skulle kännas konstigt om nån annan kom och städade bland mina möbler. Nästan som en integritetskränkning - det här ska jag ta hand om. Men också som det här skamfyllda i att nån ska ta hand om min skit.

I citatet ovan, som jag hämtar från kapitel tre, beskriver Ingrid sin ovilja att leja ut städningen i hemmet mot betalning i termer av att ta hand om sin egen skit. Hon var inte ensam om denna formulering. Även om flera av intervjupersonerna hade erfarenheter av att antingen regelbundet eller punktvis betala för städning i det egna hemmet och många dessutom själva hade arbetat med städning antingen i andras hem eller i offentliga utrymmen, uttryckte merparten en ambivalens gentemot att leja ut den privata städningen till någon annan. Detta gällde, intressant nog, även många av de intervjupersoner för vilka betald städhjälp inte var ekonomiskt möjlig. Marielle, en tjugofemårig kvinna som lever med man och tre barn, förklarar exempelvis att städhjälp aldrig har varit på dagordningen. Dels har de inte råd, men framför allt vore hon inte bekväm med att någon utomstående kom och rensade i smutsen hemma. Sådant vill hon 
helst sköta själv, förklarar hon. Och blir det kris frågar hon hellre sin mamma, då får hon rycka ut och "grovstäda".

Om oviljan att leja ut städningen mot betalning många gånger formulerades som ett politiskt ställningstagande, var det som sagt minst lika vanligt att hänvisa till vikten av att "ta hand om sin egen skit" (se även Björklund Larsen, s. 107, Hussénius 2014, s. 25). Frågan som inställer sig är därför: Vad innebär det att ta hand om sin egen skit? Vad är det med städningen i hemmet som får den att upplevas som en syssla vi bör klara själva?

En tendens i forskningen om det obetalda hemarbetet har, under senare år, varit att söka skilja på hushållsarbete och omsorgsarbete. Enligt denna uppdelning skulle hushållsarbetet, där städningen kanske är det tydligaste exemplet, lättare kunna betraktas som en sorts vara och/eller tjänst som är möjlig att köpa och sälja, medan omsorgsarbetet snarare bygger på intimitet, personliga relationer och beständighet och således blir svårare att leja ut (se Roman 2004). Denna uppdelning kan jämföras med det Ellinor Platzer talar om som rutinmässigt hemarbete kontra det som skapar engagemang och potentiell självutveckling, där städningen skulle höra till det förra. Jag kommer, framöver, att visa att denna beskrivning av städning inte helt stämmer. Snarare tycks städandet bära på en rad föreställningar om omsorg och omhändertagande, något som blir synligt i uppmaningen "att ta hand om sin egen skit». Med utgångspunkt i Joan Trontos (2013, s. 19) mer inkluderande definition av omsorg, som en aktivititet som inbegriper »everything that we do to maintain, continue, and repair our 'world' so that we can live in it as well as possible«, vill jag därför i detta kapitel fokusera på städning som omsorgsarbete. Jag väljer att närgranska och försöka bena ut de olika beståndsdelarna i utsagan var för sig: »omhändertagandet«, »det egna» och »smutsen». 
Att ta hand om - en fråga om mognad

I kapitel två beskrev jag hur städningens kroppsliga praktik aktualiserade olika lager av tid, där dåtid, nutid och framtid vävs in i varandra i intrikata mönster. Med dessa tankar i bakhuvudet vill jag nu dröja vid hur omsorgen om skräpet bär på nära kopplingar till en annan form av tidslinje, nämligen föreställningar om vuxendom och mognad. Den som håller en viss ordning omkring sig tolkas nämligen gärna som mer vuxen än den som lever med högar av osorterad post, grus i tamburen och odiskade tallrikar i diskhon. Många av de intervjuade personerna talar i termer som närmast liknar en ordningsmässig mognadsprocess: från barndomens sorglöshet och omedvetenhet om damm, över tonårens och de tidiga vuxenårens smått rebelliska ointresse för golvmopp och fönsterputs, till medelålderns reträtt till ordningen - där var sak har sin plats och det förefaller både rationellt och trivsamt med ett visst mått av ordning och reda. Adam, som är i fyrtioårsåldern, beskriver hur han med åldern har insett att han egentligen gillar att ha det ordnat omkring sig.

ADAM: Jag har aldrig varit pedant eller värderat städning som jätteviktigt egentligen. Dammsugning till exempel har jag verkligen hatat, länge. Men sånt förändras också, så på sistone har jag blivit mer intresserad av att ha lite ordning omkring mig. För jag märker att jag mår bättre. När man har mycket att tänka på är det skönt att ha det ordnat omkring sig. Det är lite trevligare faktiskt.

FANNY: Kommer du ihåg dig själv som stökigare tidigare?

ADAM: Absolut. När jag var i tjugofemårsåldern kunde det gå många, många veckor innan jag dammsög. Jag kunde dammsuga en gång i månaden kanske. Mycket saker överallt. 
FANNY: Utan att du brydde dig om det?

ADAM: Precis. Sen, när man väl städade så var det så här: oj vad skönt det var här! Att man började känna att oj, hur ska jag få nån ordning på mitt liv? Det tog ganska lång tid innan jag kopplade ihop det. Den där känslan av att man blir lite trött av att komma hem till oordning och sen så städar man och så mår man bättre.

Adam talar om den materiella ordningen som delvis liktydig med att få ordning på sitt liv. Att växa upp och bli ansvarig för sitt eget liv inbegriper, i hans resonemang, ett visst ansvar för organiserandet av närmiljön. Dammsugandet blir därigenom en sorts tecken på att han har blivit vuxen och kan ta hand om sig själv och sitt eget välbefinnande - att han följer den utstakade livslinje som postulerar att åldersmässig mognad kräver ett visst mått av städad framtoning (jfr Halberstam 2005).

I linje med detta resonemang förstår vi också hur det kan komma sig att ovälkomna intrång på ens privata städområde kan få en att känna sig i det närmaste omyndigförklarad. I ett tidigare kapitel såg vi exempelvis Ingrid drabbas av känslor av maktlöshet när hon konfronterades med sin mammas bestämda åsikter om ordning och reda. Ingrid beskriver hur hon blir som en utväxt av mammans kropp, utan egen integritet och auktoritet. Hon »dammar och vispar och rör såsom hon skulle gjort» och är hela tiden medveten om mammans tankar och kritiska blick. Ordningen är inte längre hennes egen och den vuxna kvinnan förvandlas på ett ögonblick till en liten flicka, utan vare sig makt eller ansvar.

Så ser vi hur städandet, i bemärkelsen att ta hand om den materiella omgivningen omkring sig, signalerar just vuxendom och mognad och hur oförmågan att ta hand om det egna blir ett 
tecken på motsatsen. Vi ser också hur omsorgen om det materiella tycks kunna fungera som en investering i en tänkt framtid.

ADAM: Det där med hur man har det på sitt skrivbord på jobbet, det följer också en sorts mognadsprocess tycker jag. På mina första arbetsplatser hade jag bara högar av papper, ingen ordning. Det tog ett långt tag innan jag insåg värdet av pärmar, att ordna, få in saker i en ordning. Dom sista åren på förra jobbet, då var mitt skrivbord känt för att det var det renaste skrivbordet av alla. Jag älskade det. Men nu är det faktiskt rätt stökigt där jag jobbar nu - och det beror också på att jag inte har tillräckligt med bokhyllor, jag har inte tillräckligt med pärmar och jag har för mycket att göra. Där kan jag inte riktigt hålla den där ordningen längre. Även om jag hade velat så går det inte längre. FANNY: Och hur känns det?

ADAM: Det är frustrerande. Också för att jag vill ha det ... Är man chef så ska man ha lite ordning tycker jag. Det är både för mig själv, men också utåt för företagets skull. Jag är inte nöjd som det är. Det är klart att det går att ha organisation i ett kaos, jag har levt i det så jag vet att det går. Eller man upplever sig ha kontroll i alla fall. Men det är mycket enklare, det underlättar livet om det inte bara är jag som hittar här utan att även en annan person skulle kunna hitta nånting av värde här.

FANNY: Är det det som är grejen? Att det ska vara genomskinligt även för andra?

ADAM: Framför allt att det är överblickbart för mig förstås. Men jag tänker att i rollen som chef har man också lite ansvar för att om jag inte jobbar här om tio år så ska nån annan kunna hitta bland mina papper. Det blir ju väldigt tydligt i den positionen jag är i nu där det finns en regentlängd där man kan se vem som var först, hur länge jobbade han, sen kom han och jobbade så ... 
Det finns nån slags kontroll eller ordningsmognad i mitt liv som jag tänker på när vi pratar om det här.

Adam beskriver städandet i termer av en tänkt framåtrörelse, där en viss ordning reproduceras för att säkra kommande »släkten«. Intressant i detta sammanhang är att successionsordningen inte kräver biologiska band, utan snarare kan förstås som en sorts framtidslighet frånkopplad kärnfamilj och barn. Att skapa ordning och reda på jobbet, att ha ett välstädat skrivbord och kontroll över innehållet i pärmarna, blir för honom ett sätt att signalera ansvar och mognad. Dessutom kan det tolkas som en förberedelse inför den ofrånkomliga överlämningen till kommande generationer. Genom att, som Adam formulerar det, skapa en överblickbar ordning begriplig även för en utomståendegenom att ta hand om det materiella omkring sig-inrättar han sig i en tidslinje där hans uppgift blir att utföra sitt värv för att sedan lämna över till nästa. På så sätt löskopplas säkerställandet av framtiden från den biologiska reproduktionen.

Om ett omsorgsfullt städande kan sägas signalera vuxendom och mognad, tenderar stök och smuts i hörnen att knytas till omognad, barnslighet och oförmåga att ta hand om sig själv och de sina. I ett tidigare kapitel beskriver exempelvis Göran hur hans vilja att städa innan barnens ankomst varannan vecka kan kopplas till minnen av en alkoholiserad frånskild pappa i ett alltmer ostädat hem. Omhändertagandet av den fysiska miljön blir för Göran ett sätt att visa att han (till skillnad från sin alkoholiserade pappa) är »vuxen« nog att ta hand om sina egna barn. Och Åsa, som ofta känner sig nödgad att försvara sin oordning inför besökare, förklarar att hon ibland känner sig rätt barnslig för att hon inte nödvändigtvis prioriterar rena ytor och ordning på hyllorna. 
ÅSA: Jag kan skämmas mycket när folk kommer hem till mig. Då säger jag alltid att vi har ett litet projekt som pågår här. Vi håller på med in- och utrensning säger jag, för det är ungefär ett konstant tillstånd. Så då kan man alltid gömma sig bakom det. FAN NY: Så du känner dig dum inför andra, när dom ser hur det ser ut i din lägenhet?

ÅSA: Ja, så är det nog. Jag tänker att det är nån sorts vuxengrej att det ska vara städat. Det ska liksom vara ... Man ska alltid vara beredd på att det ska kunna kliva in nån genom dörren ... Men det kan man väl vara ändå, beredd? Det är bara att du får kliva över dom där kassarna för att komma in. Alltså, jag är femtio år och det har tagit tid att acceptera den där idén om hemmet, om familjen, att det måste vara på ett visst sätt. För nu känner jag att jag bor här, det här är mitt hem och så här har vi det och vi har det ganska mysigt, liksom. Vi trivs så här. Jag tror att jag helt enkelt skiter ganska mycket i städningen. Och så kan jag inte riktigt stå för det.

Åsas ambivalenta beskrivning av sin och sonens "alternativa" ordning signalerar, som vi ser, inte enbart skam och känslor av tillkortakommande. Den genomsyras också av en kritik av de rena ytorna som symbol för mognad, ansvarsfullhet och normalt föräldraskap. I Åsas värld är annat viktigare, som de projekt hon och sonen tar sig för nere i husets grovsoprum.

Ås A: Alltså, jag är en samlare. Alltså, grovsoprummet här nere är ju fantastiskt! Nu har jag fått in min son i det också: „Ska vi gå till grovsoprummet?«»a! « Och så in där. Och vi är ju ganska många som möts där nere och bara: »Hej! Tja! finns det nåt?» Ja, sist hittade vi gamla VHS-kassetter, för vi har VHS kvar. Sånt är ju kul! 
Den lekfulla kreativitet som Åsas beskrivningar vittnar om, där etablerad ordning både vad gäller smuts och åldershierarkier får stå tillbaka för exkursioner till grovsoprummet, synliggör hur föreställningar om kaos och oordning ofta är nära knutna till kreativitet och skaparkraft. I författaren Barbro Lindgrens barnböcker om Loranga, Masarin och Dartanjang smälter just dessa teman samman i en synnerligen anarkistisk berättelse om en far som, iklädd tehuva och morgonrock, samlar tigrar i ladan, en son som mestadels ligger under bordet och äter bullar, en farfar som varje dag uppträder med nya alter egon och en giraff som bor på sophögen och knaprar på gamla stulna sängar. Ordningen, förkroppsligad av »arga gubben«, kommer då och då på besök för att styra upp och kontrollera den röriga familjen, utan någon större framgång. Snarare lyckas Loranga med vänlig tankspriddhet få honom på andra tankar, genom att bjuda på glass med Kalles Kaviar på toppen eller erbjuda en gratis tiger.

Brottet mot ordningen fungerar, i böckerna om Loranga, Masarin och Dartanjang, som en sorts förutsättning för det kreativa och egensinnigt lekfulla. Pappa Loranga har inget arbete - och är livrädd att få något. Pengar dyker upp lite här och där (huvudsakligen bakom badrumselementet), huset möbleras ständigt om efter nya lekar och garaget med sitt läckande tak har förvandlats till en bassäng, där Loranga och Masarin simmar ikapp utan att egentligen vara särskilt simkunniga.

Oordningen är alltså en källa till lust och alternativt liv. Loranga, berättelsens motor, är outsinligt kreativ- en kreativitet som inte minst bygger på ett brott mot åldersordningen. Som föräldrakaraktär har han nämligen abdikerat från det ansvar som brukar kopplas till föräldraskapet. Han bryr sig inte om huruvida sonen Masarin går i skolan, får i sig näringsrik mat eller ordentlig nattsömn. Snarare leker han och Masarin hela dagar- 
na, ibland med »krigknivar», gärna tävlingslekar, där Loranga så gott som alltid visar sig vinna enligt egenhändigt formulerade regler.

Den värld i vilken böckerna om Loranga, Masarin och Dartanjang utspelar sig är, som synes, en anarkistisk fantasi, där alla ordningar prövas, ställs på ända och byggs ihop på nya sätt. Min poäng här är att synliggöra hur denna sidovärld bygger på en distansering från den ansvarstagande, respektabla vuxenhet som inbegriper »ordning och reda och löning på fredag». Lorangas galna infall och anarkistiska hållning skulle helt enkelt inte vara möjlig utan en kapitulerad åldersordning - och en abdikation från föräldraansvaret. De kulturella kopplingar till kreativitet som kaos och oordning bär på (och som jag återkommer till senare i kapitlet), tycks med andra ord ofta gå hand i hand med idéer om bristande omhändertagande.

\section{Oordning och vansinne}

De kulturella kopplingarna mellan kreativitet, kaos och oordning rör sig också nära idéer om vansinne och psykisk sjukdom. Föreställningar om smuts, skriver Ben Campkin och Rosie Cox (2007, s. 4), är så kraftfulla att de ofta tillåts diktera normalitetens gränser. Att inte kunna ta hand om sig själv och de sina, att låta smutsen ta överhand och strunta i etablerade regler om respektabel yta, blir lätt ett tecken på asocialitet och psykisk ohälsa (Fjell 2017). Anna-Maria beskriver exempelvis hur hennes mamma, som åldrande alzheimersjuk, länge levde i ett tilltagande kaos.

ANNA-MARIA: Det var så extremt, otroligt smutsigt. Alltså, hon samlade ju... Om vi säger typ att hon plockade in tre fyllda svarta sopsäckar med papper och telefonkataloger och sånt från stan 
in i sitt hem, varje vecka. Minst tre, fyra svarta sopsäckar som jag gick och tömde. Hon hade bitvis så mycket saker att hon fick skyffla gångar i lägenheten för att hitta fram till sin stol och sätta sig. Och hon klarade inte av att slänga.

En liknande berättelse finns i Suzanne Ostens Flickan, mamman och demonerna (2016), där soporna står i centrum för mammans psykiska sammanbrott. Boken handlar om sjuåriga Ti, som bor ensam med sin sakletande mamma, styrd av de för omvärlden osynliga demonerna Polter och Geist. Allt skrot som demonerna tvingar mamman att bära hem till lägenheten måste sorteras och sedan godkännas av herr Polter, medan herr Geist bestämmer vad som får tänkas. Dottern Ti, som känner på sig att hon luktar illa och ständigt har smutsiga kläder, försöker så gott hon förmår följa mammans inre demoner.

Nätterna igenom hjälper Ti mamman att sortera skräpet enligt herr Polters principer. På morgnarna går hon till skolan, kammad och finklädd, under mammans förmaningar: »Det är så viktigt att vara hel och ren." (s.10)Allt ordnar sig, får hon veta - allt är normalt, bara det ser normalt ut. Det är viktigt, förstår Ti, annars kan människor börja undra och klaga. Som grannarna som ringer på titt som tätt och fröken som tittar på henne med forskande blick. Eller klasskamraterna, som helt sorglöst hoppar hopprep och leker bollekar med invecklade regler:

"Vi tycker om rena kläder och händer utan skrubbsår och naglar utan sorgkanter. Vi tycker att det är normalt att äta korv och fara på picknick på söndagarna och till Ikea med bilen, och att se mammor använda mikrovågsugn. Ti höll med.»(Osten, 2016, s. 31)

Den värld Ti lever i med sin mamma påminner om Barbro Lindgrens anarkistiska universum, där åldershierarkierna är 
utjämnade och alla får klara sig bäst de förmår. Men medan Lorangas alternativa ordning huvudsakligen framställs som lekfull och frigörande, styrs Mammans sorterande av destruktiva krafter som riskerar att förpassa både henne och dottern ut i vansinnets periferi. Där skräpet och oordningen hos Loranga blir närmast livgivande, skildras det alltså som motsatsen för både Ti och hennes mamma. På bokens sista sida, när vi förstår att allt havererat, grannarna larmat och fröken kanske klivit in, skriver berättaren:

"Och senare ska de städa i flera dagar, och allt ska bli rent...

Och allt ska lukta gott...

Och golvet ska bli blankt igen.

Sen kommer sommarlovet.... (Osten, 2016, s. 88)

Poängen med att dröja vid dessa beskrivningar av sambandet mellan oordning, kreativitet, barnslighet och bristande omsorg är att synliggöra den smala balansgång mellan begriplighet och obegriplighet, normalitet och vansinne som omhändertagandet av smutsen utgör. I Flickan, mamman och demonerna blir den smutsiga barnkroppen och överbelamrade lägenheten det kanske tydligaste tecknet på att något inte står rätt till och vi förstår indirekt att samhället slutligen rycker in för att återställa ordningen och omhänderta barnet.

Intressant i sammanhanget är naturligtvis också hur genus spelar in i konstruktionen av omsorg. Att ta omhand - både smutsen och barnen - är ju traditionellt en kvinnosyssla och det är därför inte svårt att tänka sig att bristande städning drabbar en kvinna hårdare än en man (jfr Ussher 2011). Vi kan exempelvis leka med tanken att byta ut karaktären Loranga mot en kvinna: en mamma som vägrar ta föräldraansvar, leker hårdhänta lekar med sitt barn och undviker all traditionell omsorg. Kanske skulle en sådan berättelse bli än mer surrea- 
listiskt befriande i sitt normbrott, kanske skulle den trilla över i skräck.

Vad jag vill peka på är att den balansgång mellan kreativitet och galenskap som bristande omsorg tycks innebära helt enkelt är genusbetingad. I essän »Hus och hem» (2000) beskriver Iris Marion Young hur hennes mamma flera gånger under hennes barndom i 5o-talets USA hamnade i klammeri med rättvisan för att hon inte förmådde hålla ordning. Fadern hade dött helt hastigt och lämnat modern ensam, förtvivlad med de tre barnen i en överdimensionerad villa i en nybyggd förort i New Jerseys utdikade våtmarker. Om mamman sällan prioriterat ordning och reda innan makens bortgång, hade hon nu mindre motiv än någonsin att städa och hålla ordning. »När försäkringspengarna och socialbidraget väl kom", skriver Young, "var vi inte längre fattiga, bara stökiga.» (s. 186) Så en vårdag kom en man i uniform till Youngs skolklass och hämtade henne och syskonen till en uppfostringsanstalt. Mamman hade helt enkelt kastats i fängelse för att ha försummat sina barn. Grannar hade klagat och barnen själva vittnade om att mamman aldrig höll snyggt $i$ huset och dessutom var svag för alkohol. Ytterligare en omgång fick mamman sitta i fängelse för påstådd försummelse av barn och hem, innan familjen flyttade från förorten till New Yorks "trygga likgiltighet" (s.189).

Att den kvinna som inte klarar av att hålla hemmet rent och välvårdat bokstavligen riskerar att omyndigförklaras är alltså uppenbart. Värt att notera är emellertid att inte heller den kvinna som lägger «alltför« mycket tid och energi på städandet går helt säker. Snarare finns det en seglivad kulturell föreställning om den överdrivet städande kvinnan som just en neurotisk, olycklig person, på gränsen till nervsammanbrott. I kapitel två beskrev jag hur efterkrigstidens hemmafru, sam- 
tidigt som hon förväntades presentera ett välvårdat hem, inte fick framstå som att hon hade "fått städning på hjärnan«. Att vara besatt av städning, ha drabbats av städmani eller husmorspedanteri är uttryck som signalerar omsorg som övergått i galenskap, något som inte minst Kristina Sandbergs romantrilogi om hemmafrun Maj vittnar om. I mina intervjuer var det heller inte ovanligt att kvinnor beskrev såväl upptagenhet av som intresse för städning som ett i det närmaste psykiskt problem, mestadels i relation till mamma och mormor, men då och då även om sig själva. Marcela förklarar exempelvis sina tidigare städmönster som ett tecken på ett osunt kontrollbehov.

MARCELA: Jag kunde säga till mina vänner: "Om du kommer hem till mig och det är så här kliniskt rent, då mår jag nog inte så bra. Men om du kommer hem till mig och det är lite städat och inte så rent då tyder det på att jag mår bra.» Och det var nog så. Mycket av mitt känslovärde gick ut på hur mycket jag städade eller inte städade, tror jag.

Lotta, som senare i kapitlet kommer att beskriva sin förtjusning i städning, är samtidigt medveten om den neurotiska kvinnotyp hon riskerar att framstå som.

LOTTA: Inre kaos, yttre ordning brukar jag säga. Jag ser ju att det finns nåt psykstört över det hela. Jag vidhåller inte att mitt sätt är det bästa eller att mitt sätt är sunt och sjyst. Utan det finns också nåt lite neurotiskt i att det måste vara på ett visst sätt. Så jag förstår ju att det inte är helt friskt och sunt, min städiver. 
Bevarandets praktik

Uppmaningen att själv ta hand om sin egen skit visar sig, som vi ser, handla om långt mer än enbart dammet i hörnen. Inte minst rymmer städandet ett alldeles eget utvecklingsmässigt imperativ, där mer ordning och renare hörn signalerar både personlig mognad och ett ansvarstagande för kommande släkten - när det görs inom rimlighetens gränser. Ett misslyckat omhändertagande av den egna skiten, det vill säga dåligt utförd städning, tenderar därigenom att tolkas som ett tecken på barnslighet, bristande omsorg och kanske i sista hand psykisk sjukdom. Vi har dessutom sett hur ordningens gränser tycks tydligt genuskodade. De negativa sanktionerna, har vi all anledning att misstänka, aktiveras tidigare för en städvägrande kvinna än för en man.

Jag ska nu vända blicken mot en annan betydelse av uppmaningen att "ta hand om" - nämligen de aspekter av bevarande som städningen inbegriper. Iris Marion Young (2000) lyfter just frågan om bevarande som central i skapande av hemmet som plats. Young hänvisar till Heideggers förståelse av boendet som människans yttersta vara, något han i sin tur menar utgörs av en kombination av bevarande och byggande. Enligt Young ägnas emellertid bevarandet sällan lika stor uppmärksamhet som byggandet. Medan det manligt kodade byggandet och konstruerandet har tolkats som produktivt, uppfattas det kvinnligt kodade bevarandet oftast som mindre kreativt och därför inte lika intressant.

Som jag tidigare har beskrivit har bevarandet även inom en feministisk idétradition tenderat att betraktas med styvmoderlig blick. Riktningen ut och bort från hemmet har resulterat $\mathrm{i}$ att hemarbetet ofta har beskrivits som ett meningslöst evighetsarbete, som binder kvinnor till en underordnad position i samhället. I Det andra könet likställer exempelvis Simone de Beauvoir 
(1949/2002) hemarbetet med det hon kallar immanens, det vill säga motsatsen till kreativitet och överskridande. Att tvätta, stryka, sopa och jaga dammråttor i mörkret under skåpen är, skriver hon, »att hejda döden, men också att förneka livet».(2002, s. 526) På så sätt är det möjligt att hävda att den som sysslar med hushållsarbete enbart får grepp om livets negativa:

»Härskaror av kvinnor delar ingenting annat än den evigt återkommande tröttheten i en kamp som aldrig leder till någon seger. (...) Få uppgifter påminner så mycket om Sisyfos straff som hushållsarbetet: dag efter dag måste tallrikar diskas, möbler dammas och kläder lagas för att dagen därpå åter vara smutsiga, dammiga och sönderrivna. Husmodern sliter ut sig genom att trampa på stället, hon gör ingenting, hon förevigar bara nuet." (2002, s. 525)

Även om Young håller med de Beauvoir om att vissa delar av hushållsarbetet är instrumentellt och föga kreativt, menar hon att det också är att betrakta som en form av skapande. Framför allt vill hon betona det specifikt mänskliga värdet i de handlingar som "syftar till att vaka över det förflutnas ting och hålla dem i förvar" (2000, s. 195). Att ordna, arrangera och ta hand om våra saker och de kroppsliga avtrycken på en specifik plats måste, enligt Young, betraktas som en minst lika kreativ aktivitet som själva byggandet av något nytt.

En viktig del av städandet och ordnandet - att "ta hand om" tingen omkring sig-inbegriper också just dessa aspekter av bevarande. Åsa, som beskriver sig som något av en samlare, berättar att hon sparar på det mesta. Gamla fakturor från decennier sedan har hon svårt att göra sig av med, inte av rädsla för skattemyndigheten utan för att de bär på spår av hennes tidigare liv. Anteckningar, kalendrar och gamla lappar sparar hon också gärna, liksom brev och fotografier. 
ÅSA: När jag var i grovsoprummet hade nån slängt ett helt liv i en sån där hattlåda, som jag tar och öppnar. Och där är, du vet, får man göra så här? Du vet, det är anställningsbevis från NK och fotografier på en ung flicka med hatt och allt. Och det bara låg där. Så jag bara: „Woop!»

FANNY: Du tog den?

ÅsA: Ja, det märkliga är att jag hade hittat en liknande hattlåda med saker från min morfar tidigare som jag hade sparat. Så jag satt där med min egen släkt och så var det nån annans släkt som bara kom in i mitt liv. Så nu har jag den också här. Den där lilla sorgliga lådan, nån har slängt nån annans liv. Jag bara: „Näee!» Så jag måste ta hem den, så att åtminstone jag har sparat den här människans liv. Jag fick känslan av att hon som hade hamnat i gropsoprummet, att hennes barn inte tyckte om henne. Alltså jag fick en känsla av att det hade hänt någonting. Alltså, att de bara: „Vi vill inte ha den här gamla skiten, vi vill inte ha henne kvar.» För mig är det helt obegripligt att man kan slänga en massa fotografier, det går inte. Men det är massor med människor som gör så antagligen, som bara: „Den här gamla skiten ska vi inte spara, nu går vi vidare.» Jättemärkligt är det. För det var inte bara hattlådan som var där, utan det var ett helt hem där i soprummet med mattor, köksutrustning, ett bibliotek, LP-skivor. Och man bara: »Hon har levt ett liv i det här och sen bara dör hon och sen rafsar dom ihop allting och kör ner till grovsoprummet och ingenting finns kvar. Nothing.» Det är liksom väldigt märkligt.

I Åsas berättelse ser vi hur hennes ordnande och sorterande till stora delar kretsar kring bevarande - just det som Young påpekar att mycket hemarbete går ut på. Centralt i Åsas beskrivning är hur den materiella omgivningen, tingen hon ordnar och ombesörjer, vittnar om avlagringar av liv. Det är människors liv 
hon tar hand om när hon sparar hattlådor och gamla LP-skivor: mikrohistorier som annars skulle glömmas eller gömmas i soprum och på avskrädesplatser.

Att ta hand om de dödas liv är också en av slutsatserna Melanie Lovatt (2015) drar utifrån sina intervjuer om erfarenheter av att sortera gamla släktingars kvarlämnade saker. Lovatt beskriver hur tingen intervjupersonerna valde att spara inte enbart associerades med specifika personer, utan till och med uppfattades konstituera dem. Så kunde det bli omöjligt att slänga en avliden närståendes pyjamas, tofflor eller rökdon - inte för att någon någonsin skulle vilja återanvända dem, utan för att det upplevdes som att kasta själva människan i sopnedkastet. Att ta hand om sin gamla mammas saker blev, i denna bemärkelse, liktydigt med att göra sig till en ansvarstagande familjemedlem-och samtidigt upprätthålla en kontinuitet både bakåt och framåt i tiden.

När jag tidigare, med hjälp av Söderbäcks begrepp revolutionär tid, diskuterade hur ett fokus på kroppsliga praktiker kan ge andra perspektiv på historia än den linjära tidsuppfattningen, vill jag här återigen poängtera hur städandets alldeles specifika temporalitet skapar en kontinuitet mellan det förgångna och nuet. Den kan, i denna bemärkelse, sägas förankra människor över tider och mellan kroppar - en förankring utan vilken vi, med Youngs formulering, bokstavligt talat skulle vara »förlorade». (2000, s. 194)

Återvinningens tid

Åsas omhändertagande av tingen kan således tolkas som ett historiskt omsorgsarbete, där sakerna hon räddar symboliserar andra människoliv i förfluten tid. Det kan också formuleras i ter- 
mer av återvinning, en praktik som röner ett allt större intresse i det globala nord i form av klädbytardagar, bakluckeloppisar och sopsortering (Åkesson 2012, Appelgren och Bohlin 2015). Inbyggd i diskursen om återvinning, som fått stort gehör inte minst i Sverige, finns en samhällskritisk dimension, som inbegriper en distans till marknadssystemets överproduktion av varor.

I Managing Overflow in Affluent Societies beskriver Orvar Löfgren (2012) hur västvärldens konsumtion sedan efterkrigstiden antagit delvis nya former. Ett ökat överflöd för såväl medel-som arbetarklassen skapade rum för ökad konsumtion, inte minst av varor som tv-apparater, bilar, båtar, kläder och hushållsapparater. Alltfler branscher började arbeta enligt en modell där förra säsongens mode framställdes som hopplöst passé och som något som med nödvändighet måste ersättas av dagsaktuella nyheter. Så kom konsumtionstakten att speedas upp på ett sätt som inte skådats tidigare.

Även konsumenternas attityder förändrades under denna tidsperiod. Lena Larsson, en inflytelserik debattör i frågor om konsumtion och formgivning, myntade begreppet »köp-slitoch-släng" för att markera att en gammal tid nu måste ersättas av en ny. I denna nya tid var människor, enligt Larsson, mindre brydda om tingen omkring sig. Hennes uppmaning var att slänga ut det rigida och traditionstyngda och istället satsa på enklare, billigare och mer informell inredning. Bort med gamla dammiga tavlor och in med affischer, ut med obekväma soffbord och in med praktiska möbler. I boken Vill våra barn ärva våra ljusstakar? (1970) beskriver hon inredningen hos en ung familj som ett tecken på den nya tidens mentalitet:

»Möbleringen är av intresse. Här är det snarare status att inte äga saker, man har inga möbeltyper i konventionell bemärkelse. Man har inte städmani...(...) Man nöjer sig med öppna hyl- 
lor, gärna från golv till tak med allting synligt, ett stort bord och billiga fällstolar. Rymliga utbredningsbord för arbete och lek behövs, liksom bra sängar. Vad saknas? Soffgruppen, fåtöljerna och de mjuka, dyra materialen! Inga tavlor, hellre lätt utbytbara tryck, affischer. Man är öppen för nyheter om de är bra, dvs. praktiska.» (Larsson 1970, s. 122)

Denna 1960-talets rörelse mot en informalisering av konsumtionen (och i förlängningen av livet) kan betecknas som en reaktion mot äldre generationers konsumtionsmönster - ett uppror där studenter och den unga radikala medelklassen gick i bräschen. Samtidigt, påpekar Löfgren (2012), var utvecklingen mot en mer informell och flexibel livsstil en bredare rörelse i tiden. Den ritualiserade privatkonsumtion som kännetecknade tidigare generationer, där heminredning såväl som klädinköp följde tydliga normer och rutiner bundna av tid, situation och plats, var nu skjuten i sank. Intressant nog, påpekar Löfgren, är det just denna förskjutning mot större flexibilitet och informalisering som underbygger den successivt ökade konsumtion som vi sett sedan dess, inte minst under 1980-talet (som brukar beskrivas som överkonsumtionens årtionde per excellens). Konsumtionskritiken kom alltså, paradoxalt nog och helt ofrivilligt, att bana vägen för en ökad konsumtion.

Denna utveckling är intressant att ha i bakhuvudet när vi försöker förstå samtidens ökade intresse för återvinning och återbruk. Om systemkritiken på 196o-talet formulerades som ett behov av att kasta bort det gamla för att skapa nytt och eget, är rörelsen idag snarast motsatt. Framför allt ligger fokus på att hantera överflödet snarare än de gamla traditionerna. Förvaring har blivit ordet på allas läppar och möbelföretaget Ikea säljer numera inte enbart smarta förvaringssystem utan även 
kurser i hur du organiserar dina prylar på bästa sätt (Cassinger 2010, Löfgren 2012). Den japanska organisationskonsulten Marie Kondo har sålt miljoner böcker världen över på temat förvaring (bland annat med titlar som The Life-changing Magic of Tidying Up) och Margareta Magnussons (2017) uppmärksammade bok Döstädning proklamerar vikten av att, över åren, rensa bort onödiga prylar för att göra vardagslivet mer smidigt och lustfyllt.

Lösningen på problemet med överflödet av ting verkar alltså vara att ordna tingen på mer rationella sätt, att helt sonika slänga dem, eller att låta bli att köpa nytt och istället återanvända gammalt. Denna rörelse mot återanvändning och återvinning har tolkats på en mängd olika sätt: som en möjlighet till kreativitet och lekfull estetisering, en sorts rekreation eller ett sätt att fortsätta konsumera med små ekonomiska medel (Appelgren och Bohlin 2015, s. 4). Inte minst har det analyserats som ett (i viss mån) civilisationskritiskt sätt att hantera konsumtionssamhället: att skapa en alternativ miljömedveten etik i relation till tingen omkring oss (jfr Franklin 2011, Fredriksson 2013). ${ }^{21}$

I detta kulturella sammanhang blir bevarandet av tingen, såsom exempelvis Åsa tidigare beskrev sina raider ner i hyreshusets källare, en aspekt av städning som helt enkelt ligger i tiden. Att "ta hand om» det materiella kan således tolkas både som ett sätt att skapa kontinuitet med det förgångna och att investera i en mer hållbar framtid.

Att pilla med sina saker-omsorgens sinnlighet

Det finns emellertid ytterligare en aspekt av städandets bevarande praktik som jag vill uppmärksamma. Förutom att samla, 
ordna och organisera tingen omkring sig (som Åsa beskriver), inbegriper omhändertagandet nämligen en rad ännu mer repetitiva sysslor såsom att damma, sopa, torka av och putsa. Johanna beskriver hur just dessa praktiker genererar en alldeles särskild relation till tingen och ytorna i hemmet.

JOHANNA: Alltså, när jag tittar på den där fåtöljen till exempel är det som att jag har en relation med den, för jag vet hur jag har torkat av den. Alltså lite så. Det är som en relation helt enkelt. Ja, vad heter det?

FANNY: Taktilt?

JOHANNA: Ja, nåt taktilt, precis. Men inte bara taktilt utan också nåt som har att göra med smak och lukt och känsel. Sinnlig. Ja, sinnlig! Det är en väldigt sinnlig upplevelse att städa. Det är både sinnligt och rumsligt. Och andligt också tycker jag faktiskt. Det är något just med att veta att den här, här är den här, fast den här torkar jag ju inte på det sättet. Som att man skulle kunna känna till en annan människas kropp, hur den känns och vad den vill ha. Det är som en relation, fast en relation till rummet och sakerna. (skratt)

Johanna beskriver hur just de sysslor som av många upplevs som enformiga, repetitiva och tröstlösa, möjliggör en sorts fysisk relation med det materiella. Att återkommande ta på sina saker, känna in vad de behöver och hur de vill bli omhändertagna beskrivs som en nästintill andlig upplevelse - en sorts relation med tillvaron. Kanske är det också därför Johanna talar om städningen som en ytterst personlig syssla, något hon definitivt inte skulle vilja lämna bort till andra att utföra. 
JOHANNA: Förra gången jag flyttade köpte jag en sån här flyttstädning och blev väldigt missnöjd med det. Och liksom också lite ledsen, det kändes som om jag nästan ångrade det. Inte riktigt så starkt kanske, men det var nånting med att lämna mitt hem till dom. Jag tyckte inte att dom städade lika fint, inte på det sätt som jag tyckte det skulle vara. På nåt sätt påminner det om en kärlekshandling, helt enkelt, städningen. Man visar att man tar hand om det stället där man bor, om sitt bo, och att det är nånting fint med det. Det är som en läkande process, nåt reparerande eller vad jag ska säga. Det är nåt med att ta hand om. Jag tror att man kan säga att jag liksom "pillar med mina saker". Att det är trevligt att pilla med sina saker, helt enkelt. Det är det jag gör, tror jag. Jag tar på mina saker helt enkelt, går igenom dom och tycker att det känns tryggt. I mitt bo. Att alla sakerna är där dom ska vara. Så tror jag att det är lite grann.

I likhet med Åsa uttrycker Johanna sitt städande som en omsorg om det materiella. Att ta hand om sitt bo, genom att ordna, sortera, damma, putsa och sopa, formuleras som i det närmaste en kärlekshandling. Städningen av det egna hemmet beskrivs som en djupt personlig syssla, som därför ogärna lejs ut till utomstående. Tingen kräver helt enkelt personlig omsorg för att ta formen av ett hem - och den personliga omsorgen kräver i sin tur en viss sorts kroppslig närvaro. Johanna talar om det som att hon "pillar med sina saker", en formulering som signalerar en introvert, nästintill lite hemlig, intimitet. Det tycks också vara just denna kroppsliga närvaro som borgar för det reparerande och läkande drag som Johanna beskriver städningen ha. Den trygghet som ett eget bo innebär bygger helt enkelt, i Johannas beskrivning, på ett ömsint "pillande med" och ordnande av sina saker. 
Sin egen och de sina

En annan aspekt av Johannas pillande med sina saker är att det skapar gränser mellan mig och dig, det egna hemmet och andras. Det är pillandet med sina egna saker hon beskriver med sådan värme. I mina försök att förstå uppmaningen ratt ta hand om sin egen skit» vill jag därför dröja vid mellanledet »sin egen«. Vad utgör den egna skiten för de intervjuade personerna och vad har definitionen av det egna för betydelse för själva städandet som syssla?

Mandy, som är i dryga trettioårsåldern, beskriver att hon upplever vardagsstädningen helt annorlunda sedan hon separerade och skapade ett eget hem för sig och sitt barn.

MANDY: Numera känner jag att jag väljer att städa, det är ingen som går under om jag inte gör det. Socialen kommer inte banka på min dörr. Okej, det kanske skapar problem i mina sociala relationer, men jag måste inte. Sen jag har skaffat mitt eget boende med mitt barn så har det blivit som en stärkande ritual för mig, att ha hand om mitt. Det är mitt tempel som jag ser det, mitt hem som jag har byggt upp. Jag vet hur mycket ansträngning som ligger bakom. Jag har liksom skapat mitt eget space där jag trivs, där jag får plats att tänka tankarna som jag vill tänka och då är det viktigt för mig att ha det rent och fint.

Från att tidigare ha uppfattats som ett tvång och en ständig källa till bråk verkar städningen, när den sker på egna villkor och i relation till det egna hemmet, snarare upplevas som något njutningsfullt: en »stärkande ritual». Liknande känslor beskriver Lotta, som lever med sin flickvän och två bonusbarn. 
LOTTA: När min sambo och ungarna åkte till fjällen i påskas och jag skulle vara hemma ensam, då laddar jag liksom för att jag ska få städa. Detär det jag ser fram emot allra mest. Och inte bara städningen i sig, utan att jag - alltså det liksom vattnar sig i munnen bara jag pratar om det - att jag ska städa och så ska jag vakna dagen efter och så ska det vara likadant. Den tillfredsställelsen! Så jag laddar för det här, att dom ska åka iväg. Min sambo hade lite dåligt samvete och tyckte synd om mig, men jag bara: „Du, tyck inte synd om mig." Och det var ju inte bara städningen, utan också att få vara ifred och tänka. Men städningen var en del av det. Och sen tänkte jag såhär: så fort dom lämnar lägenheten så vet jag att jag kommer ha ett sånt pass härinne, jag kommer springa så att svetten rinner. Men så kunde jag inte hålla mig! (skratt) Jag kunde bara inte hålla mig! »Men gud, ska ni aldrig...! Ni skulle ju med bussen, sa ni ju!« Jag kunde bara inte låta bli att smygbörja lite innan dom hade åkt, typ härinne, och dom var därute med sina enorma packningar och skidor. Och så känslan av att detta ekipage, detta berg av packning, går ut ur lägenheten. Jag var nere med dom och bara: »Hejdå! Och sen bara upp i lägenheten och sen körde jag loss! Och då ser det inte ut såhär, kan jag säga. Då är det bara helt jävla fucking kliniskt. Då går jag grundligt till väga. FANNY: Vad är skönt med det? Är det skönt efteråt, eller under tiden?

LOTTA: Det är väl att det ser så fräscht ut. Att det känns så fräscht. Alltså, jag njuter, så jag kan inte med ord beskriva hur jag njuter när dom åker iväg och jag får göra allt det där.

FANNY: Men du njuter av både görandet och efteråt.

LOTTA: Båda delarna. Ja. Ja, det är ett lugn. Som att ta sobril. Fast utan segheten. Du vet ... Ja, det är som att ta sobril fast utan dåset. Man kan säga såhär: det är som en sobril spetsad med lite amfetamin! 
Den njutning Lotta beskriver att städningen framkallar hos henne kretsar, som vi kan se, kring det ensamma ordnandet av hemmet. Hon kan knappt bärga sig tills barn och sambo försvinner iväg på semester innan hon »kör loss». Att helt och hållet få koncentrera sig på städandet, att ordna och fixa enligt eget huvud och, inte minst, vara ifred med sina tankar framkallar en tillfredsställelse att likna vid ett rus.

Både Lottas och Mandys upplevelser av städningen som något njutningsfullt och tillfredsställande kan sammanfattas med kontrollen över det egna. Att ha ett eget hem att ordna med, där du själv har bestämt reglerna och själv sätter ramarna för standarden. Även om båda två lever tillsammans med andra människor tycks det vara självbestämmandet, det vill säga att slippa ta hänsyn till dessa andra, som är förutsättningen för njutningen - något jag diskuterade kort i kapitel tre.

Allra mest njutningsfull verkar städningen bli när den utförs i ensamhet. I Lottas fall framkallar barnens och sambons frånvaro ett tillstånd av eufori och Mandy beskriver hur hon aktivt organiserar sin tillvaro så att ingen, varken vänner eller barn, kan störa henne de timmar hon lägger på städningen (eller, kanske minst lika viktigt, de timmar av nystädat hem som följer på den intensiva insatsen). När sysslan är självvald, avgränsad och sker i ensamhet utan störande moment utifrån kan alltså omhändertagandet om den egna skiten uppfattas som ett tillstånd av njutning och kontemplation. Så kan vi också förstå Johannas försök att förklara tjusningen i att städa hemmet:

FANNY: Tycker du om att städa?

JOHANNA: Ja, det tycker jag om, jättemycket! Jag tycker väldigt mycket om att städa faktiskt. Fast inte gränslös städning, utan 
som en slags ... Vad ska man säga då? Som nånting man upprepar enligt ett slags schema.

FANNY: Som en rutin?

JOHANNA: Som en rutin, ja. Det är viktigt att det inte blir oändligt. Då skulle det inte vara skönt, tycker jag. Utan det är just att man gör det som en slags rutin som jag har bestämt helt själv. När jag hittade på den här städordningen som jag har nu - för det är ju lite tossigt, jag kan fatta det också och det kanske skulle vara svårt om jag bodde ihop med någon - att få vara precis såhär som jag är. Och att jag kan njuta extremt av det, att jag får göra precis som jag vill med just dom här grejerna. Att det inte är nån som kommenterar det eller retas, utan jag får göra precis som jag vill. För mig är det en väldig frihetsgrej. Att jag får vara mig själv, helt ifred, och bara göra det här på ett skönt sätt. FANNY: Och vad är det du tycker om med själva städandet då?

JOHANNA: Det är nog tillståndet när jag städar. Det är som att tankarna flyter. Eftersom jag har bestämt mig för hur jag ska göra, det är som ett schema som jag följer. Det är inte någon improvisation över huvud taget, utan det är alltid i en speciell ordning. »Då tar jag den trasan, då tar jag den och sprutar där» och så, i en speciell ordning. Då behöver jag ju inte tänka på det, utan jag gör samma sak hela tiden. Det känns som att jag har hittat ett »flow« i det där. Det är väldigt härligt! Det är som en ritual som gör att jag samtidigt, märker jag, liksom också städar ur mitt inre på nåt vis. Alltså att det också kommer upp en massa känslor i kroppen när jag städar. Saker som, ja, det är ett sorteringsarbete rent mentalt. (skratt)

FANNY: Hur då?

JOHANNA: Jag tänker att det som är väldigt rituellt frigör nånting annat. Det gör liksom att man inte behöver tänka på vad man ska göra. Det är väldigt ångestdämpande helt enkelt. För 
man bara åker med en stund i en slags: „först här, sen det där, sen det därı. Ja, det ena äter det andra på nåt sätt. Och då händer det grejer, som nån slags meditation. Det går inte ens att säga att »då löste jag det där problemet». För det är inte så. Det är mer som att det åker upp saker till ytan och så försvinner det, och så åker det upp. Men så efteråt känns det som att det har varit nån slags rening liksom, inuti. (skratt)

I Johannas beskrivning finns alla de beståndsdelar som tycks kunna få städningen att uppfattas som njutningsfull: den utgör ett ensamt, avgränsat, självvalt projekt, på egna premisser. Intressant att notera är hur det repetitiva, ständigt återkommande - det som vanligtvis brukar beskrivas som hemarbetets förbannelse - är en viktig förutsättning för hennes positiva upplevelse. Hon beskriver städandet som en rutin, ja till och med som en ritual, där hon får möjlighet att sortera inte bara den materiella omgivningen utan även tankarna och tillvaron i stort.

I sin undersökning om hemarbete och vardagsvanor poängterar Sarah Pink (2004) vikten av att betrakta sysslor som diskande, städning och hemdekorering som både meningsskapande och kreativa. Hon kritiserar tidigare forskare som bland annat beskrivit diskande med betoning på dess mekaniska och icke-intentionella karaktär: »a mindless yet embodied activity involving 'the numbing of self in a stifled life' or a refuge from the complexities of intentional action« (2004, s. 47).

En analys av Johannas positiva upplevelser av städning leder i motsatt riktning. Det är snarare genom det rutinartade mekaniska som hon finner ro och njutning: att få möjlighet att låta tankarna flöda fritt inom ramarna för en strikt och självvald ritual. Om vi återkopplar till hennes tidigare beskrivning, där 
hon formulerar de läkande aspekterna av att "pilla med sina saker", ser vi hur omhändertagandet om "det egna» kan tolkas som en form av självomsorg, där omsorgen om den materiella omgivningen helt enkelt samtidigt blir ett sätt att ta hand om sig själv.

Omhändertagandet av »det egna» innehåller alltså en potentiell njutning - kanske särskilt när sysslan är avgränsad, självvald, i ensamhet och på egna premisser. Samtidigt är ju detta sällan fallet. »Den egna skiten« inbegriper ofta även andra människors skit, människor med egna viljor och annat sinne för tajming och ordning. Omhändertagandet av den egna skiten är därför ofta mer att likna vid en relationell praktik, en syssla som inbegriper fler än enbart en individ. Kanske kan vi till och med tänka oss att det privata städandet sätter ramarna för vilka som ingår i den egna omsorgskretsen, vilka som räknas till de närmsta. Att städa i hemmet:åt sina barn, sin gamla mormor, sin sambo eller sig själv, blir då att betrakta som ett socialt kitt, som i sig vidgar det egna till det kollektiva och därigenom skapar gemenskap. Att inte lyckas städa såsom förväntas av en familjemedlem, som vi tidigare såg Kristina beskriva sin relation till sin mamma och syskon, kan snarare generera ett brott med gemenskapen.

Kanske syns städningens funktion som socialt kitt som allra tydligast när omsorgens gränser tangeras - när vem som tillhör gemenskapen blir en fråga för förhandling. Kerstin, som är i femtioårsåldern, beskriver hur städning blivit en knäckfråga i den bonusfamilj hon lever i.

KERSTIN: Om man har varit med ett barn sen det var litet och man har haft all den här fysiska kontakten som man har med mindre barn, då är inte deras skräp och stök äckligt. Men min 
bonusdotter kom in i mitt liv i tonåren. Hon hade det så extremt stökigt att jag tyckte att det var äckligt. Kanske var det tonårsstök, Martin sa att hon alltid hade haft det stökigt, men i tonåren blev det nog ännu värre. Det låg skitiga och rena kläder om vartannat i hennes rum, en massa gammal mat, det luktade illa och instängt och det var dammigt och kladdigt och mensgrejer på golvet. Det kunde sova över fyra brudar i en säng i ett rum som var åtta kvadratmeter flera nätter i rad utan att dom ens öppnade fönstret. Och det var hår överallt, för dom höll på att färga håret också. Att försöka förmedla till en biologisk förälder som har varit med sitt barn sedan det var pyttelitet att den där stökigheten inte bara är irriterande, utan också äcklig... Min sambo tog oerhört illa upp för han trodde att jag tyckte att hans barn var äckligt. Men jag stod inte ut. Till slut fick faktiskt Martin städa toaletten på övervåningen där hon bodde. Jag tyckte att det blev för äckligt. Kunde inte hjälpa det.

FANNY: Tror du din reaktion hade att göra med att hon var ditt bonusbarn?

KERSTIN: Ja. Jag tror att många bonusfamiljer kan få problem med just barnens stökighet. Att bonusföräldern ofta har mer fysisk distans till barnen när man kommer in lite senare i deras liv. Då kan man lätt uppleva den här stökigheten som påträngande. Jag skäms lite såhär i efterhand för att jag tyckte att det var äckligt. Men det är också svårt när man inte kan säga åt barn som man skulle kunnat om dom var ens biologiska. När Julia kom hem kunde hon slänga väskan på golvet, sen slängde hon jackan på golvet, slängde sjalen på golvet och vantarna och skorna i var sitt hörn av hallen. Sen sa det pang så var hon inne i sitt rum. Jag bara suckade när jag såg det där. Men sa jag nåt, blev det bråk. Inte bara med henne utan också med hennes pappa. 
I Kerstins beskrivning ser vi hur ordningen i hemmet blir central i görandet av gemenskap och familj. Städningen är, som hon beskriver det, en av de största anledningarna till bråk och slitningar. Olika förväntningar, städstandard och sätt att hantera tonårsstök blir direkta avspeglingar av vem som hör till familjen och inte. Själv tolkar hon sin känsla av äckel inför bonusdotterns oordning som ett tecken på sitt relativa avstånd - att hon helt enkelt inte har samma kroppsliga närhet till barnet som den biologiska föräldern.

I boken Smuts diskuterar Olli Lagerspetz (2006) intimitetens roll för människors upplevelser av smuts och renhet. Han exemplifierar med att den egna saliven sällan upplevs som obehaglig och kanske heller inte saliven hos en älskad person. Däremot framstår ofta andra människors saliv som obehaglig, för att inte säga äcklig. Gränserna för vad som uppfattas som äcklig smuts är på detta sätt knutet till graden av intimitet och närhet. Dessutom är äckelkänslor beroende av om intimiteten är självvald eller påtvingad, påpekar Lagerspetz. Personer som exempelvis blivit utsatta för sexuella övergrepp, alltså en synnerligen påtvingad form av intimitet, beskriver ofta sig själva som smittade med just den smuts de upplever förövaren ha/vara.

I Kerstins fall tycks graden av intimitet vara central för hur hon hanterar bonusdotterns upplevda stökighet. Att inte ha varit nära över lika lång tid som den biologiska föräldern genererar, som hon beskriver det, fler potentiella äckelkänslor. Samtidigt ser vi hur hennes försök att komma nära och bli en del av gemenskapen, genom att propsa på att få vara med och sätta ramarna för ordningen, avvisas. Uppmaningen att ta hand om sin »egen« skit blir i detta sammanhang en kanske särskilt laddad fråga, genom att den indirekt aktualiserar vem som hör till familjen och inte. 
Att familjeband både görs, försvåras och kanske till och med omöjliggörs genom städandets praktik vittnar även Johanna om, när hon beskriver relationen till sin nu bortgångna mamma.

JOHANNA: Mamma hade en period när jag var liten när hon mådde väldigt bra. Då renoverade hon hela lägenheten, tapetserade och målade om och sådär. Och städade, så att det var prickfint. Hon tyckte om när det var städat. Men sen bar det liksom utför. Alltså min tonårsperiod minns jag som väldigt rörig och stökig och kaotisk. Och jag tror att det var jag som städade hemmet då. Jag har så dåliga minnen av det, jag minns inte. Men jag kan ibland drömma mardrömmar om att det är väldigt rörigt, att det är lådor med saker som bara väller ut, som har samlats under väldigt lång tid. Väldigt jobbiga drömmar. FANNY: Och din mamma städade mindre och mindre, eller? JOHANNA: Ja, jag har en känsla av det. Och sen städade hon inte alls. På sommarstället till exempel var det ju fruktansvärt äckligt och stökigt. Då har jag känslan av att man var där och städade och sen blev det lika stökigt igen. Att man till slut inte orkade mer. Och att det var en massa skuldkänslor runt att inte hjälpa till att städa, att man borde hjälpa mamma med det. Men att det inte gick, mentalt, för att det var så helt meningslöst. Att det bara grodde igen direkt, att det var lika bra att hon fick göra som hon ville, då. Hon fick göra som hon ville. Men det var en resa att kunna slappna av med det, att tänka att hon får göra som hon vill, och jag får göra som jag vill. Men det betydde ju också att jag inte kunde dela hushåll med mamma. Alltså fyra nätter max, kanske bara tre. Och då var även det ganska jobbigt. Mycket på grund av det här stökeriet faktiskt, det var det som var den jobbigaste grejen. 
Till skillnad från Kerstin beskriver Johanna en relation där familjebanden sällan ifrågasätts. Att en mor förväntas ta hand om sina barns smuts uppfattas som i det närmaste en självklarhet. Barnen (och kanske framför allt döttrarna) förväntas i sin tur återgälda omsorgen när modern blir gammal nog att själv behöva omvårdnad (se t.ex. Brodin 2005, Ulmanen 2015). I Johannas beskrivning ser vi emellertid hur hon, efter åratal av försök att få sin obändiga, oförmögna mamma att upprätthålla ordningen, ger upp. Den omsorg hon själv delvis upplevt sig sakna, i form av städad miljö, orkar hon heller i slutändan inte hjälpa sin mamma med. Det var inget enkelt beslut, förklarar hon, att låta mamman sköta sitt och själv sköta sitt eget - inte minst för att det avbrutna ansvaret gör det svårare att samsas under samma tak längre än några få dagar. På så sätt ser vi hur synen på vad som utgör »den egna» skiten och andras blir central i definitionen av familj och nära relationer. Annorlunda formulerat synliggörs hur intimitet och distans, både inom och utanför den sanktionerade familjen, regleras genom hanterandet av den gemensamma smutsen.

Med Johannas berättelse i bakhuvudet blir det spännande att reflektera över den uppmärksamhet som Margareta Magnussons bok Döstädning rönt sedan den publicerades 2017. Magnusson vill visa på värdet av att rationalisera bort prylar för att på så sätt skapa sinnesfrid i vardagen. Men titeln (med undertiteln »ingen sorglig historia") syftar också på den slutgiltiga städningen, det rensande av livets prylar som tänks underlätta för eventuella efterlevande. En av Magnussons poänger är helt enkelt att vi bör hålla efter sakerna i vår vardag, både som en omsorg om oss själva och av hänsyn till eftervärlden. Att boken snabbt exporterats till ett tjugotal länder, på engelska med titeln The Gentle Art of Swedish Death Cleaning, vittnar om ett up- 
penbart behov av att diskutera det ansvar vi har för vår egen och vår nästas smuts i en värld kännetecknad av individualisering och kulturell friställning.

I detta perspektiv blir det också intressant att titta närmre på barns roll i städandet av hemmet. Få av de föräldrar jag intervjuade var helt nöjda med sina barns delaktighet i den rutinmässiga städningen. Vissa av dem hade helt gett upp, andra lade sig på en lägre nivå än de egentligen ville för att slippa tjat och ytterligare andra var nöjda med en relativt liten insats från barnens sida. Många jämförde med sin egen barndom, och upplevde sig ha tagit långt större ansvar för städningen hemma än vad de egna barnen gör nu. Och någon förklarade att barnen huvudsakligen lärt sig det lilla de kunde om städning från vistelser på sommarkollo.

I sin essäbok om städning reflekterar Maria Antas (2013) över hur barnböcker skildrar just barns delaktighet i städandet av hemmet. Som exempel tar hon sjuttiotalsklassikern Totte städar, i vilken författaren Gunilla Wolde (1970/2014) med realistiska teckningar och informativt anslag beskriver ett barns ordnande av sina leksaker. Totte städar för att hitta sin försvunna nalle, men också för att han helt enkelt inser att det är trevligare att ha det rent och fint omkring sig. Insikten kommer till honom av sig själv, i hans ensamhet. Mamma och mormor är någon annanstans. Trettio år senare konstaterar Antas att städningen är långt mer konfliktladdad. Åtminstone som den skildras i barnböcker som Snurran städar (Bergström 2009) och Vem städar inte? (Wirsén 2011). Här bråkar föräldrar med varandra och, framför allt, på bångstyriga barn som inte vill vara med och ta ansvar. Som i de flesta barnböcker slutar emellertid även dessa i harmoni, städkriserna avhjälps och lugnet lägger sig över lördagen.

Medan Antas noterar den ökade graden av konflikt, funderar 
jag själv över hur de olika skildringarna kan tänkas illustrera en successiv förändring i synen på barns roll och delaktighet i familjen. 190o-talet har beskrivits som barnets århundrade, under vilket barn fått ökade rättigheter och skydd. Detta betyder också ett tabu mot barnarbete och ett förkastande av synen på barnet som en potentiell arbetskraft. Snarare än en extra hjälpande hand, fyller barnet i dagens västerländska samhälle rollen som en känslomässig investering för sina föräldrar: en person att ösa kärlek, ömhet och intimitet över (James, Jenks och Prout 1998, Edelman 2004). Med en sådan barnsyn är det kanske inte så märkligt att städningen - en syssla som av många upplevs som trist och enahanda - lätt hamnar mellan stolarna. På min fråga huruvida Iris och hennes sambo brukar involvera sina barn i familjens städning, svarar hon såhär:

IR IS: Jag vet inte om det är obehaget kring städningen som gör att man inte vill dra in barnen i det. Ja gud, det var en samvetsfråga. Varför gör man inte det? Man kanske inte vill umgås med dom. (skratt) Faktiskt. Är det inte så att man ibland bäddar för mjukt på olika vis för att man inte vill konfronteras med dom? Jag tänker att städning är som en riktig konfrontation, som är... Ja, jag vet inte, jag är konflikträdd och jag tror inte att jag skulle vilja öppna det där, allt jag känner och tänker om städningen och hur arg jag är för att vi har det som vi har det. Jag är arg på dom också för att vi har det som vi har det, på nåt sätt. FANNY: För att dom stökar till?

IR IS: Dom stökar till. Ja, men det är som med matlagning. Varför drar man inte in barnen i matlagning? Ja, för att det går fortare om man gör det själv och så kanske man vill ha en stund för sig själv. Städningen, då är man åtminstone själv i huvudet. Och ska man dra in dom i det... Hälften handlar då om att instruera 
dom och det kanske man inte alltid vill och orkar. Fast det är ju det som är livet. Så det kan jag få panik över också - att man inte på riktigt är med dom, utan att dom på nåt sätt underhålls. Livet igen. Dom har inte kontakt med det som är grunderna för att vi finns här ... Ja, jag vet inte. Och jag tror inte att jag vill utforska det heller.

Iris försök att svara på varför hon inte propsar på att barnen ska vara mer delaktiga i städningen kretsar, som vi kan se, kring just intimitet och avstånd. Snarare än ett hänsynstagande till barnen, beskriver hon det som en sorts distansering. Dels vill hon få vara själv med sina tankar, något städningen ger möjlighet till. Men städning är också, som hon formulerar det, en syssla som riskerar att riva upp sår och generera konflikter. Hon vill helt enkelt inte bjuda in barnen till den del av sitt innersta där otillräckligheten och ilskan över sakernas tillstånd härjar okontrollerat. Samtidigt uttrycker hon sorg över att varken orka eller våga släppa de allra närmsta inpå livet - att inte introducera dem även till livets »smutsigare» sidor.

En fråga om integritet

Hittills har jag visat hur omhändertagandet av den egna skiten kan analyseras som en omsorg om sig själv, de sina och den materiella omgivningen, liksom ett sätt skapa kontinuitet bakåt och framåt i tiden. Städandet av det egna hemmet blir i detta perspektiv att betrakta som en, av nödvändighet, ytterst personlig syssla som inte helt enkelt kan lejas ut till utomstående. Många gånger upplevdes städningen som både viktig och njutningsfull. I andra fall (som jag visat prov på i tidigare kapitel) beskrevs den emellertid som ett ok, något som tenderade att 
hamna mellan stolarna och skapa dåligt samvete. Att, trots denna ovilja, klara av att ta hand om sin egen skit formulerades i dessa intervjuer ofta som en fråga om autonomi och integritet - som både Iris och Laura svarar på frågan varför de inte kan tänka sig att låta någon annan städa deras hem.

LAU RA: Alltså jag tycker att det är okej att man kan ta hjälp med allt möjligt under perioder. Men jag tycker inte det är rimligt att man ordnar sitt liv så att man inte klarar sig utan hjälp när det gäller såna tingliga saker som städning, om du förstår vad jag menar. Då känns det som att man har sträckt sitt kungadöme lite för stort helt enkelt. Att man blir lite girig med sin tid. IR IS: Det sitter nog i att man inte ska låta nån annan ta hand om det där som jag själv har såna hemska känslor kring. Nån som ska vara i vår smuts. Och så skam att man inte kan ta hand om det. Att man inte klarar det, att man inte håller ihop det. Det skulle vara som ett ultimat misslyckande på nåt sätt. Att man inte bär sig själv, det är mycket det. Att man inte kan snurra sig runt sin egen axel, att man lever för stort på nåt sätt, att man har tagit på sig för mycket. Och att då köpa en lösning, det blir som ännu värre. Det blir som ytterligare en bekräftelse på att hjulet snurrar för fort, man kan inte ta hand om det man har tagit på sig. Då konsumerar vi ännu mer, så köper vi en lösning på problemet.

Iris och Laura formulerar, som synes, sin ovilja att låta någon annan ta hand om »den egna skiten« som en fråga om autonomi och självständighet. De vill helt enkelt kunna ombesörja sig själva och de sina, vara oberoende av hjälp utifrån - annars skulle det kännas som om de hade tagit sig vatten över huvudet eller "sträckt kungadömet för stort». Till skillnad från andra sysslor 
knutna till hemmet (såsom exempelvis omsorg om barn och äldre) urskiljer sig alltså städningen som en uppgift de upplever sig behöva klara själva. Ingela, som är av samma åsikt, formulerar det som en fråga om intimitet:

INGELA: Jag tycker att hyfsat unga friska människor ska städa efter sig själva.

FANNY: Varför då?

INGELA: Det har väl med gränser att göra. Det finns inget rationellt skäl egentligen. En del kanske tycker att nån ska komma hem och borsta tänderna åt dom också. Det har att göra med vad man tycker är nivån på personlig hygien. Jag tycker att bor man så stort att man måste ha städerska så ska man skaffa sig en mindre bostad.

Ingela pratar om privata gränser och personlig hygien. Om att jobbet som ska göras i det närmaste är att betrakta som en del av hennes egen kropp och att hon därför helst gör det själv. Såtillvida formuleras städningen av det egna hemmet som en fråga om integritet - vi släpper inte gärna in utomstående i det mest privata. Men det har också att göra med att det är smuts som ska avlägsnas, inte barn som ska passas eller blommor som ska vattnas. Oviljan att leja ut sysslan handlar alltså, till stor del, om smutsen i sig-om avlagringarna, det som blir över och ska bort. För att på allvar förstå innebörden i uppmaningen att ta hand om sin egen skit ska jag därför nu fördjupa mig i själva »skiten».

\section{Skiten}

En central aspekt av städning är det repetitiva momentet. Städandet måste, med jämna mellanrum, upprepas för att hem- 
met inte ska gro igen. Denna sisyfosartade verksamhet liknar i mångt och mycket annat omsorgsarbete. Maten måste på bordet varje dag, födelsedagar dyker upp med jämna mellanrum och blommor ska då och då vattnas. Till skillnad från exempelvis matlagning och födelsedagsuppvaktningar är emellertid städningen huvudsakligen preventiv - den är som mest framgångsrik när den inte märks. Poängen är inte att skapa något synligt, i form av en väl uttänkt present eller en god maträtt. Städningen som uppgift innebär snarare att försöka upprätthålla status quo genom att hålla undan det ovälkomna. Samtidigt är det, som vi vet, svårt att hålla jämna steg med smutsen som ständigt hotar att invadera det mest ordningsamma hem. Dammet som samlas i hörnen, de otrevliga beläggningarna som tenderar att få fäste i toalettstolen och matresterna i diskhon blir obönhörliga påminnelser om att smutsen tenderar att invadera - om vi inte ständigt håller efter och är på vår vakt.

FANNY: Kan du beskriva dina känslor kring städningen?

IRIs: Det upptar större delen av min tid att tänka på städning och allt som borde städas. Det är bara en kort stund som jag är lycklig och det är när det är klart. All tid är ju tiden innan städning, på nåt sätt. Det finns ingen tydlighet, att nu tar jag tag $\mathrm{i}$ det, utan det är mer att jag försöker gå runt och hålla kaoset stången på nåt sätt. Det är konstant obehag, kryp, ångest kring att det inte är städat som jag vill. Jag tycker jag småplockar hela tiden och sen kan jag ha ryck på helgerna. Då jag ägnar kanske två timmar åt att städa intensivt och då kan det vara en tillfredsställelse efteråt. Men sällan så som jag minns förr, från tiden innan familjen. Då var det en helt annan tillfredsställelse, då kunde man verkligen få det fint på riktigt. Man visste att allt var rent, man var framme liksom. 
FANNY: Har du en längtan efter att det ska bli klart, att du ska komma fram?

IRIS: Ja, och få göra nåt annat än att tänka på det. Att få vila. Få sitta ner och titta på hur fint det blev. Att det är färdigt. Förhoppningen att man kan ägna kraften åt nåt annat.

FANNY: Så du skulle säga att det pågår i huvudet hela tiden när du inte precis har nystädat? Just nu då, vad tänker du nu?

I R IS: Jag tänker på disken. Det luktar lite svagt vitlök här och jag har en gäst hemma och undrar om hon känner det. Tänker på att det förmodligen var hon som tog bort disken. Det är den där känslan av att jag ser vad jag skulle kunna ta bort, men det är ändå meningslöst för det är bara en sån försvinnande liten del av allt som ska göras. Jag ser tidningarna och dammet på fönsterbrädorna, på elementen, på lampan som lyser ser jag dammet som ligger som en hinna och listerna under diskbänken som har som en fet kladdig hinna, som jag aldrig kommer komma till. Så svårt det är.

FANNY: Och varför är det störande med dammet på lampan och kladdet på listerna?

I R IS: Det är väl den där känslan av att det är så hopplöst mycket och att jag aldrig kommer komma fram till den där punkten då man är färdig och får vila och känna sig fri. Jag vet inte vad som är så farligt med det. Att det är kladdigt och smutsigt. Jag trivs inte i det. Det är tröstlöst på nåt sätt.

I Iris beskrivning innebär städningen att ständigt försöka hålla kaos stången och att ständigt uppleva sig misslyckas. För, som hon formulerar sig, nall tid är ju tiden innan städning« - och den tid som hon kan sätta sig ner och pusta ut i ett nystädat hem är försvinnande kort, om den någonsin infinner sig. Att aldrig bli fri från uppgiften att hantera kaos, att 
aldrig få känna sig framme, genererar känslor av hopplöshet och uppgivenhet.

IR IS: När det kommer folk som aldrig har varit här förut, då vill man göra den där städningen. Om man bjuder folk på middag som man inte har haft hemma. Så gör jag den lite med gråten $\mathrm{i}$ halsen för att det är ganska meningslöst och samtidigt tittar jag upp på den där väggen som är halvt tapetserad och den andra som saknar tapet. Och där samlas det fullt med flott från fläkten som inte funkar. Så stannar man upp där med skurkäppen och känner att vad fåfängt det här är att ens försöka. Men ändå, jag är ju jättenoga med att det ska vara rent på toan, dammsuget och att disken i alla fall är undanplockad.

Andra intervjupersoner beskriver hur det ständiga förfallet, den invaderande smutsen, får dem att uppleva ilska och känslor av att vara orättvist behandlade.

LOLLo: Det kan bli så fruktansvärt kaosigt så snabbt! Det är så taskigt på nåt sätt, så står man där och gör fint. Ja, jag skulle säga att det är det som får mig att tycka så illa om städning, jag blir lite kränkt. (skratt) Jag tycker faktiskt det är lite taskigt. Man har just gjort i ordning och så har man en fika, en middag, kanske nån sover över och man bjuder på frukost och går hemifrån. Sen när man kommer hem så liksom: „Va?« För jag kanske har dukat undan lite snabbt för att ha det trevligt eller nåt. Och då kan jag tycka att det här är ovärdigt och liksom orättvist, just. (skratt) För jag har ju precis städat. Och så kanske det kommer nån just då också och ringer på och bara:»Oj då.« Man bara: »Det var inte så här i förrgår, faktiskt.» 
I dessa berättelser blir det uppenbart att de känslor som genereras av städningen inte enbart kan lokaliseras till sysslans repetitiva karaktär, det vill säga något som även kännetecknar annat omsorgsarbete. De har också att göra med själva skiten som sinnebilden för nedbrytning och förfall. Iris beskriver sig få panik över att hemmet ständigt är på väg att "gro igen« och Lollo känner ilska över att smutsen alltid tycks vinna över hennes smått fåfänga försök att hålla ordning i köket.

Som jag beskrev i inledningen hävdar Mary Douglas (1966) att samhällets syn på smuts handlar om ordning och oordning snarare än om hygien och renlighet. "Smuts kränker ordningen", skriver Douglas (1966/2011, s. 10), som menar att smutsen måste definieras som allt som hamnat på fel plats. Obehaget inför dammtussarna i hörnen och smutstvätten på sovrumsgolvet - och viljan att städa undan - skulle alltså kunna förstås som en rädsla för oordning i största allmänhet. Var sak på sin plats garanterar, så att säga, det enskilda livets liksom samhällets ordning.

Douglas relativiserande syn på smuts har emellertid kritiserats för att vara alltför svepande och abstrakt. I antologin Dirt pläderar exempelvis Carol Wolkowits (2007) för vikten av att undersöka människors praktiska handhavanden av och förhållningssätt till smuts, snarare än att röra sig på ett symboliskt och teoretiskt plan (se även Lagerspetz 2006, Campkin och Cox 2007). Risken finns annars, menar Wolkowits, att den »faktiska» smutsen försvinner till förmån för mer abstrakta resonemang om gränsöverskridanden och tabun. ${ }^{22}$

Med Wolkowits kritik i minnet vill jag dröja en aning vid den differentiering av smuts som jag anar i intervjuerna. För även om oordning (dvs. saker på fel plats) skapar irritation, tycks smuts i form av damm och klet väcka en alldeles särskild sorts obehag. I Iris berättelse utlöser flottet som oundvikligen samlas 
ovanpå köksfläkten och dammet som kladdar fast på golvlisterna en skräck som hon beskriver sig ha svårt att bemästra. Det verkar helt enkelt existera en vag men ändå intressant skillnad mellan oordning och smuts, som jag vill undersöka närmre. Liksom tidigare i kapitlet vänder jag mig till skönlitteraturen för att komma åt vad jag är ute efter.

\section{Det ostädade skåpet}

I en sekvens i Sent i november skildrar Tove Jansson (1998) Filifjonkans frustration över att, hals över huvud, ha flytt sin egen misslyckade storstädning och vidhängande liv till en Mumindal som visar sig vara tom på folk. Familjen är borta och kvar i den höstlika dalen är endast ett antal vinddrivna existenser som alla, av en eller annan anledning, har sökt sig dit. Snusmumriken letar efter en borttappad sommarvisa, Homsan Toft längtar efter en mamma han aldrig haft och Hemulen vill lära sig vad frihet och äventyrsliv innebär. Filifjonkan själv har tappat riktningen hon mår instinktivt illa vid tanken på storstädning och inte ens matlagning tycks längre kunna skänka henne någon ro. Dessutom har hon en omisskännlig känsla av att det gror i husets alla skrymslen och vrår, att de ostädade garderoberna är befolkade.

"Filifjonkan reste sig långsamt. Hon såg att skåpet var tomt. Men ut ur det dammiga mörkret kom en förfärlig, främmande lukt - det var förruttnelsens kvalmiga och söta doft. Inne i skåpet fanns inget annat än en maläten kaffelapp av ylle och en mjuk matta av grått damm. Filifjonkan böjde sig ner, rysande. Var det inte små spretiga spår i dammet, helt små, nästan omärkliga ... Något hade bott i skåpet och blivit utsläppt. Allt det där som kryper fram när man vänder på en sten och som kravlar under förmultnade växter, hon visste, nu hade det kom- 
mit ut! Det hade kommit ut med prasslande ben, med rasslande ryggsköldar och trevande spröt eller krälande på vita mjuka magar ... Hon skrek: Homsa! Kom hit! och homsan Toft kom ut ur sin skrubb, han var skrynklig och förvirrad och stirrade på Filifjonkan som om han inte kände igen henne. Han spärrade upp näsborrarna, här fanns en mycket stark lukt av elektricitet, frisk och frän.

De har kommit ut! ropade Filifjonkan. De har bott därinne och nu har de kommit ut!« (Jansson 1998, s. 8o)

Filifjonkans skräck för det ostädade skåpet är, som vi kan ana, en skräck för det som gror och växer i skymundan, när vi vänder ryggen till. Smutsen blir till ett inkräktande ovälkommet djur, en naturkraft som släpps lös om vi inte hela tiden håller undan och tar kontrollen. Liksom i Iris beskrivning, upplever Filifjonkan en skräck för att smutsen ska bli henne övermäktig, att den ska flytta in och ta över hela hennes värld. Och liksom i Iris beskrivning har dammet och skiten ett alldeles eget liv, bortanför salongsmöblemang och te-serviser. På så sätt kan vi också tänka oss att smutsen skiljer sig från oordningen. Båda utgör, med Douglas teori, ett potentiellt hot mot samhällsordningen. Men medan oordningen skapas av mänskliga händer, i form av saker placerade på fel plats, tycks smutsen snarare vara självgenererande. Dammråttorna växer i hörnen utan att vi själva tycker oss ha något med saken att göra. Det förfall som dammet, kladdet och kletet symboliserar talar alltså inte nödvändigtvis enbart om ett potentiellt samhälleligt kaos, utan också om annat liv, bortanför den ordnade världen. Ett icke-mänskligt liv, bortanför civilisationen, som sätter alla våra till synes fåfänga försök att skapa ordning i skräckinjagande perspektiv. 
En civilisationsprocess?

Hur ska vi då förstå den rädsla som smuts genererar? Sigmund Freud (2014/1930) talar i termer av »organic repression« för att definiera kulturens upptagenhet av renhet. Det civiliserade samhället bygger, menar han, på en kontroll av annat organiskt liv. Att vara smutsig, lukta illa och låta diskbänken gro igen uppfattas därför som antisocialt och ociviliserat, som en sorts utmaning mot samhällsordningen. I Freuds förståelse blir hanterandet av smutsen en central aspekt av det civilisatoriska projektet.

Detta antagande ligger i linje med hur exempelvis Norbert Elias (och senare Michel Foucault) beskrivit utvecklingen mot ökad civilisation i framför allt västvärlden. Som jag kortfattat beskrev i inledningskapitlet argumenterar Elias för att ökad renlighet och självbehärskning kännetecknar framväxten av den moderna individen. Framför allt, hävdar han, var den successivt förändrade inställningen till smuts avgörande för hur social kontroll försköts från en yttre till en inre styrning. Civilisationsprocessen innebar att människor alltmer började kontrollera sina begär och behov, inte minst kroppsliga sådana. Från att ha uppfattats som en integrerad del av gemensamt liv blev sjukdom, död, sexualitet, kroppsvätskor - ja, all sorts personlig "smuts» - en privat angelägenhet, som helst skulle hållas hemlig. Genom att studera historiska handböcker i uppförande beskriver Elias hur denna förändring, som startar hos adel och överklass för att sedan sippra ner till borgar- och arbetarklassen, kan avläsas i de mest vardagliga vanor. Exempelvis börjar det uppfattas som ouppfostrat att snyta sig i näven, prutta och kissa offentligt och äta med händerna. Istället förväntas den civiliserade människan använda bestick, näsduk och dass.

Boel Berner, som undersökt handböcker i renhållning runt 
sekelskiftet 19oo, beskriver en liknande utveckling. Från att det tidigare inte varit så noga med hygienen hemmavid, framställdes det rena hemmet nu som ett tecken på såväl civilisation som moral och respektabilitet. Inte minst signalerade det rena hemmet sundhet, något som accentuerades i och med upptäckten av bakterier under 18oo-talet. Att hålla hemmet rent och, med ett nytt modeord, hygieniskt blev ett sätt att försöka undkomma de luftburna partiklar som tänktes bära med sig farlig smitta (se även Cox 2007). Städning formulerades således alltmer som en vetenskapligt belagd, medicinsk nödvändighet.

Detta innebar delvis förändrade städvanor. Dammsugaren var exempelvis en produkt som, trots att de första exemplaren var både tunga, dyra och sög dåligt, kom att uppfattas som ett nödvändigt hjälpmedel för att avlägsna det ohygieniska dammet (Forty 1986, Tafvelin 2002). Eftersom bakterier inte kan urskiljas med blotta ögat, var det emellertid omöjligt att veta när städningen var tillfredsställande utförd. I en skrift utgiven på 1920-talet av dammsugarföretaget Elektrolux avslöjas vad ett endaste gram damm kan innehålla - förutom fragment av bomull, ull, hår, hudavfall, sandkorn och dylikt: »1 ooo ooo bakterier som vore utvecklingskraftiga vid rumstemperatur. Åtskilliga arter bakterier som alstra smittosamma sjukdomar förefunnos.» (citerat ur Tafvelin 2002, s. 15) Städningen antog således alltmer formen av ett ständigt pågående krig mot potentiella bakterieburna katastrofer.

Civilisationsprocessen, med sin beskrivning av en successiv utveckling mot allt större renlighet, självdisciplinering och autonomi, är en väl använd modell inom kulturhistorisk forskning. Den har emellertid inte stått helt oemotsagd. Olli Lagerspetz (2006) kritiserar exempelvis Norbert Elias forsk- 
ning för att vara dåligt empiriskt underbyggd. Han menar att det är svårt att uppskatta nivån av renlighet under historiskt avlägsna tider, inte minst bland de grupper och klasser som sällan lämnat några egna skriftliga vittnesmål. Vi vet helt enkelt inte om de torftigt inredda rummen i 18oo-talets torparhem var skitigare än den borgerliga våningen med sina tunga tyger och prydnadsföremål. Det är heller inte nödvändigt, menar Lagerspetz, att den skit vi bedömer som snuskig idag, uppfattades så då. Att de medeltida städerna stank av urin och ruttnad mat är en samtida grundmurad föreställning. Men att vi, idag, tänker oss stanken som outhärdlig betyder inte att dåtidens stadsbor upplevde den som värre än hur det exempelvis luktade på en vanlig bondgård.

Lagerspetz (2006, s. 148) föreslår att det, snarare än en enhetlig civilisationsprocess, handlar om att tidigare former av disciplinering har försvunnit till förmån för andra. Däremot, menar han, är det svårt att bortse från ett successivt framväxande ideal om renlighet, som i sin tur sammankopplas med självbehärskning och framsteg. Smuts blir helt enkelt ett tecken på allmänt lösaktigt beteende (i bemärkelsen vårdslös, snuskig, sexuellt lössläppt, ociviliserad), medan renhet likställs med självkontroll, ansvar och »högkultur«. Sammanblandningen mellan smuts, snusk, sexualitet, lättja och dålig moral kan anas exempelvis i uttryck som »självbefläckelse» (onani) och »renlevnad» (nykter- och avhållsamhet).

Renhetsidealet användes i sin tur för att skapa och accentuera skillnader mellan samhällsklasser. De som fötts in i eller tillägnat sig »högkultur» och bättre levnadsstandard kunde således definiera andra grupper som smutsiga och därigenom sämre. Så ser vi hur exempelvis svenska utvandrare till 180o-talets Amerika beskrevs som en alldeles särskilt smutsig sort 
(Larsmo 2016) eller hur människor från andra kulturer än den västerländska historiskt (och delvis än idag) har konstruerats som ohygieniska (Mudimbe 1988, Azar 2001).

Den politiska viljan att civilisera de breda lagren skedde även, från 18oo-talet och framåt, till viss del med hygieniska förtecken (något vi i förra kapitlet såg manifesteras i Hemmets forskningsinstitut). I Ellen Keys visionära skrift Skönhet för alla (1899) knyts god estetik, något hon menar bör komma alla till del, till det lättstädade och hygieniska. Och när Ludvig Nordström på 1930-talet reste runt på den svenska landsbygden för att dokumentera fattigdom och nöd var det i termer av smuts och renhet han formulerade sin politiska uppmaning till förändring och "vägen ur Lort-Sveriges snusk och elände" (1938, s. 429). En liknande uppmaning återfinns hos Martharörelsen (en förening som under 1900-talet bedrev upplysningsarbete bland finska husmödrar), vars uppdrag var »att rensa ut likgiltigheten, snusket och smutsen som uppfattades som fattigdomens kännetecken" (Marander-Eklund 2014, s. 109).

\section{Smuts och liv}

Denna smutsens funktion som skillnadsskapande människor emellan betyder emellertid inte att vissa grupper eller samhällsklasser saknar idéer om eller praktiker kring renhet och oordning. Detta är en av Mary Douglas poänger i Renhet och fara. De västerländska föreställningarna att det egna förhållningssättet till renhet handlar om hygien, medan andra samhällens upptagenhet av renhet och smuts snarare är av symbolisk karaktär, fastslår hon som felaktig. Douglas undersökning visar snarare hur hanterande av smuts, både i västvärlden och andra kulturer, handlar just om en sorts organisering av samhället. 
Städning, det vill säga att återställa saker till dess rätta plats, måste således betraktas som en central praktik i upprätthållandet av samhällsordningen. På samma gång erkänns också oordningens potentiella kraft att förstöra och i förlängningen vittna om och generera annat liv. Oordning, skriver Douglas (1966/2011), symboliserar nämligen inte enbart fara, utan även kraft. Smutsen, som normalt sett betraktas som skadlig och farlig, kan också bli skapande - just genom att den synliggör andra möjliga ordningar (s. 223).

Som jag tidigare beskrivit tycks smuts ofta upplevas som just en främmande kraft, som ständigt tenderar att ta över de egna försöken till ordning och renhet. Den uppgivenhet med vilken Iris tidigare formulerade sin vånda över det tilltagande dammet på fönsterbrädorna och diskbänkens ständigt kladdiga hinna, vittnar om att denna kraft lätt uppfattas som skrämmande. Samtidigt finns här också ett erkännande av liv - en annan sorts liv-som kan tänkas vara potentiellt livsbejakande. Dessa tankegångar anas i Åsas tidigare beskrivning av sitt sparande och bevarande av gammalt "skräp». Trots att hon ofta känner sig föranledd att försvara sin relativa oordning inför besökande gäster, är hon påfallande tillfreds med sakernas tillstånd. Istället för att slänga och organisera prioriterar hon att återanvända och bygga vidare.

ÅsA: Jag är inte en slängmänniska i första hand, utan saker flyttas runt tills jag fått nog. »Nu ska den ut.» Så är det. För man kan alltid ha användning av allting. Man kan inte slänga, man kan alltid göra nåt av grejerna: bygga och pyssla och sånt ... Jag har till exempel en enorm kasse med såna här frigolitskivor i garderoben som är jättejobbig och som smular sönder och strös ut överallt och skapar en massa damm. För den kan vi nämligen 
bygga rymdskepp av är det tänkt. När vi nu ska göra det. Och den får jag inte slänga, jag har försökt.

FANNY: För din son?

ÅsA: Ja, jag har försökt lite så.

FANNY: Var det han som kom på att man kunde bygga rymdskepp eller är det du som tänker att...

ÅsA: Nej, men han kom på, eller vi kom på det tillsammans: "Mamma, dom här kan vi spara, dom kan vi göra nånting med", säger han. »Ja«, säger jag, »kanske ett rymdskepp!« Man präglar väl honom också. Det är mycket sånt som man ska göra.

Åsas garderob blir en illustration av Mary Douglas resonemang om smutsens/oordningens potentiellt livsgenererande kraft. Frigolit, ett material som sällan brukar associeras med klädgarderober, tillåts ligga där och samla damm i väntan på att omvandlas till ett rymdskepp. Saker placerade på fel plats blir här visserligen smuts, men en produktiv sådan, ur vilken det är möjligt att skapa annat liv. Douglas (1966, s. 227) menar också att det utgör en del av våra mänskliga villkor att den renhet vi strävar efter, när vi väl uppnått den, visar sig vara »hård och död som sten«. Detta eftersom renhet står i motsats till förändring, tvetydighet och kompromiss. Samtidigt som ordning, i Douglas förståelse, är central i upprätthållandet av samhällsordningen, tenderar den alltså att kväva det liv som uppstår genom den potentiellt farliga tvetydigheten. Detta är något Johan noterar, som en reflektion över sin egen vilja till ordning och reda.

JOHAN: Begränsat med saker som har sin egen plats, det har nog varit mitt ideal. Men jag tror att det börjar förändras lite grann, numera kan jag ändå vara ganska stolt över vår röra. Jag tror jag har börjat förknippa mitt eget ideal med nån form av 
livlöshet. Jag kan trivas som vi har det nu: att det snabbt uppstår röra, att det kommer in saker som jag inte vet var de kommer ifrån, som en påminnelse att det händer nånting, att livet pågår.

Oordning och stök blir, i Johans beskrivning, inte enbart en påminnelse om förfall. Det är också ett tecken på att liv pågår, att människor kommer och går, drar in skit och ställer stolar på fel ställen. Att släppa en aning på den tänkta ordningen och låta smutsen gro i hörnen skulle i detta sammanhang kunna tolkas som en livsbejakande hållning. Samma inställning anar vi hos Kristina, när hon i ett tidigare kapitel beskriver sin mammas energiska städande och kliniska ordning som en anledning för den livsnjutande fadern att fly hemmet. Och hos Anna-Maria, som inte känner sig helt välkommen i alltför perfekt städade hem.

ANNA-MARIA: När jag kommer till ett hem där allting ligger perfekt, då känner jag att jag inte kan röra mig, jag kan liksom inte leva i det. Jag skulle aldrig kunna leva med en människa som var helt pedantisk. Då får jag lite ångest nästan. För då känner jag att jag inte lever mitt liv, att jag liksom inte får plats.

Ta hand om sin egen skit

Vad betyder då uppmaningen att ta hand om sin egen skit och vad säger den om städning som syssla? I förstone kan vi sluta oss till att vi har att göra med en praktik som inte enkelt låter sig karakteriseras och definieras. Trots att handlingarna som utförs är synnerligen konkreta - att damma, sopa, torka och ställa till rätta är ju sysslor som framstår i det närmaste banala i sin konkretion - tycks städningens karaktär svår att komma åt. Det är som om symbolen ställer sig i vägen för praktiken och prakti- 
ken i sin tur för symbolen. I detta kapitel har jag därför försökt komma åt städningen så att säga lite från sidan, genom att närgranska betydelserna av den allmänt spridda uppmaningen att ta hand om sin egen skit. Det visar sig då att städning uppfattas som en form av omsorgsarbete: en omsorg knuten till mognad, vuxendom, ansvar och respektabilitet. Städandet av hemmet skapar sammanhang, gemenskap och familj, såväl framåt som bakåt i historien. På så sätt blir städningens praktik att betrakta som en omsorg om både sig själv och andra.

Till skillnad från annat omsorgsarbete är emellertid städning ett omhändertagande av det förfallna, vilket gör den till en särskilt ambivalent syssla. Såtillvida skriver den in sig i en symboltyngd historia om civilisation som framåtskridande, där den som ansvarar för städningen både bokstavligen och symboliskt riskerar att dras ner i »skiten". Problemet med ett alltför envetet fejande kan dessutom vara ett potentiellt förtryckande av möjligt annat liv. Den som städar alltför minutiöst riskerar att döda det liv som städningen var tänkt att möjliggöra. Städandet blir därför, snarare än ett tydligt urskiljbart uppdrag eller arbete, att betrakta som ett ständigt medlevande med tingen och smutsen - det vill säga en sorts omsorg om smutsen snarare än kontroll över den.

I sin kritik av Mary Douglas och hennes efterföljare propagerar Olli Lagerspetz (2006) för vikten av att undersöka hur människor lever med smutsen, snarare än att betrakta den symboliskt. Detta kapitel visar på ett påfallande sätt hur livet med smutsen är djupt sammanflätat med symbolerna som omger den och de praktiker som måste tillämpas för att avlägsna den. 